\title{
A Study on Consumer Buying Behaviour towards Nokia Mobile in Erode District
}

\author{
Dr. M. Velumani \\ P.k.r arts college for women, pariyur road, gobichettipalayam, Erode-638 476.
}

\begin{abstract}
In Present Marketing Scenario, the Study of Consumer Behavior has become essential. Consumers are the kings of markets. Without consumers no business organization can run. All the activities of the business concerns end with consumers and consumer satisfaction. Customer behavior study is based on consumer buying behavior, with the customer playing the three distinct roles of user, payer and buyer. Consumer buying behavior has become an integral part of strategic market planning. In order to develop a framework for the study consumer behavior it is helpful to begin by considering the evolution of the field of consumer research and the different paradigms of thought that have influenced the discipline. As described in this article, a set of dimensions can be identified in the literature, which can be used to characterize and differentiate the various perspectives on consumer research. It is argued that consumer behavior itself emerged as a distinct field of study during the 1960s; and is characterized by two broad paradigms, the positivist and the non-positivist. The positivist paradigm, which is still the dominant paradigm, emphasizes the supremacy of human reason and that there is a single, objective truth that can be discovered by science. The opposing, non-positivist paradigm, envelops the interpretive and postmodern perspectives, which have emerged more recently during the period post-1980 to date. The rational view and the ideology of a homogenous social culture and thereby deny the complex social and cultural world in which consumers live. The objective of non-positivist research endeavor is to achieve a better understanding of consumer behavior with no specific intent to influence consumer processes. This article aims to identify different streams of thought that could guide future consumer research.
\end{abstract}

Keywords: Consumer Buying Behavior, Traditional Perspectives, Rational Perspectives, Cognitive, Traits, Conventional, Attitudinal, Situational.

\section{Introduction}

Consumer buying behaviour is the sum total of a consumer's attitudes, preferences, intentions and decisions regarding the consumer's behaviour in the marketplace when purchasing a product or service. Consumer Buying Behaviour refers to the buying behaviour of the ultimate consumer. The study of consumer behaviour draws upon social science disciplines of anthropology, psychology, sociology, and economics. Satisfaction is a function of perceived performance and expectation. If the performance falls short of expectation the customer is dissatisfied. If the performance matched the expectations, the customer is satisfied. If the performance exceeds expectations, the customer is highly satisfied or delighted.

A consumer's buyer behaviour is influenced by four major factors such as cultural, social, personal and psychological factors. These factors cause consumers to develop product and brand preferences. Although many of these factors cannot be directly controlled by marketers, understanding of their impact is essential as marketing mix strategies can be developed to appeal to the preferences of the target market. When purchasing any product, a consumer goes through a decision process. This process consists of up to five stages: Problem recognition, Information search, Evaluation of alternatives, Purchase decision, Post purchase behaviour.

The main focus of analysing consumer buying behaviour is to identify, buyers reactions towards nokia's marketing strategy that has a great impact on the firm's success, the marketing concept stresses that a firm should create a marketing mix that satisfies (gives utility to) customers, need to analyse that what, where, when and how consumers buy and needs to predict, how consumers will respond to marketing strategies.

The major problem is that it links their products either to the attainment of love and belonging, or by linking those products with people similar to those with whom people would like to associate. Prestige is another intangible need, and those concerned with status will pay for it. However, goods appealing to this type of need must be viewed as high-profile products that others will see in use. One benefit of targeting this type of market is that the demand curve for luxury products is typically the reverse of the standard; high-status products sell better with higher prices.

\section{Statement of Problem}

The researcher analyses consumer buying behaviour in order to understand,

- Why consumers make the purchases that they make?

- What factors influence consumer purchases? 
- The changing factors in our society.

A survey has shown that many elements contribute to make it more difficult in finding consumer's buying behaviour. The elements are:

- Lack of knowledge of the market.

- Lack of brand awareness and external motivators.

- Lack of satisfaction level of customers.

- Lack of awareness about the perception \& expectations of the customers.

- Lack of awareness about the

\section{Review of Research and Development}

Mr. Durra Mansoor in his study "Consumer behaviour is the study of the processes that individuals or groups go together in making their purchase choices in order to satisfy their needs". It is valuable to mention that the consumer behaviour is a combination of customer's buying awareness combined with external motivators to result in a change in the consumer's behaviour.

Nesbitt(1959) points out that "smart customers do not make their shopping list in advance because they will seek promotions and tend to earn more benefits from them to increase their purchasing power".

Mr.G.Shaniesh in his study "Buying behaviour in a business market is characterised by long cycle times, group decision making, participants from different functional areas and levels and sometimes divergent objectives, and changing roles of the participants during the buying cycle".

\section{Objectives of the Study}

- To find out the factors influencing to prefer Nokia mobile.

- To find out the need of purchase of Nokia mobile.

- To study the socio-economic characteristics \& awareness of Nokia mobile users.

- To find out the level of Satisfaction towards Nokia mobile.

- To study the problems faced by the customers regarding Nokia mobile.

\section{Methodology}

The validity of any research depends on the systematic method of collecting the data, and analyzing the same in appropriate order. In the present study, an extensive use of both primary and secondary data was collected. In this study, descriptive research was used.

\section{Data Collection}

An extensive use of both primary and secondary data was collected. The primary data was collected from the nokia mobile users of sathyamangalam town. The information was gathered through structured questionnaire method. The secondary data was collected from journals, magazines and websites.

\section{Sample Design}

There are number of nokia mobile users. The researchers have approached respondents in nokia showroom to collect the data. For collecting the information, the respondents were chosen by non-probability random sampling.

\section{Scope of the Study}

The present study is confined to erode district and considers only various models of Nokia Handset. Though the main objective of the study is to analyse customer preference in Nokia Handset and the factors influencing them to purchase a particular model, the scope of the study extends to the following related aspects viz., the socio economic characteristics of the respondents, the awareness of Nokia handset users, level of satisfaction towards Nokia mobile and the problems faced by the customer.

\section{Tools of Data Collection}

By virtue of mass data obtained from the research survey as well as data collected from secondary sources, descriptive research was considered as most appropriate one for the study. The research problems and the questionnaire were all framed accordingly. The core of the study being "A consumer buying behaviour towards nokia mobile in erode district" is to mainly find out the factors influencing the consumer to buy the nokia mobile. These factors were studied through percentage analysis, Garret ranking method, Chi-square test and ANOVA. 


\section{Conclusion}

The researcher had made an effort to find out the level of buying behaviour of nokia mobile in erode district and it is clear that the public have high awareness on nokia services. Nokia mobile services attract people because of its quality, model, price, services and memory capacity in nokia mobile. Hence it is concluded that if the nokia mobile has come out with effective advertisement it may highly influence the consumer to purchase nokia mobile.

\section{Bibliography}

[1]. Adams, G.A., King, L.A., \& King, D.W. (1996). Relationships of job and familyinvolvement, family social support, and workfamily conflict with job and lifesatisfaction. Journal of Applied Psychology, 81(4), 411-420

[2]. Alam, M.S., Biswas, K., \& Hassan, K. (2009). A Test of association between workinghour and work family conflict: A glimpse on Dhaka's female white collarprofessionals. International Journal of Business and Management, 4(5), 27-35.

[3]. Allen, T. D. (2001). Family-supportive work environments: The role of organizationalperceptions. Journal of Vocational Behavior, 58(3), 414-35.

[4]. Allen, T.D., Herst, D.E.L., Bruck, C.S., \& Sutton, M. (2000). Consequences associated with work-to-family conflict: A review and agenda for future research. Journal of Occupational Health Psychology, 5, 278-308.

[5]. Anil Kumar, C.S., \& Krishnan, S.K. (2005). Balancing work and life-the new age dilemma. Human Capital, August, 48-53.

[6]. Aryee, S. (1992). Antecedents and outcomes of work-family conflict among married professional women: Evidence from Singapore. Human Relations, 45(8), 813-835 